\title{
STUDENTS' PERCEPTION IN LEARNING ENGLISH USING COOPERATIVE LEARNING ACTIVITY
}

\author{
Irma Kharisma $^{1}$, Liza Andhani Hidayati ${ }^{2}$ \\ IKIP Siliwangi ${ }^{1}$ \\ IKIP Siliwangi ${ }^{2}$ \\ ${ }^{1}$ Ikharisma112@gmail.com, ${ }^{2}$ Andhani10@gmail.com
}

\begin{abstract}
This study aims to know the students' perceptions about the use of cooperative learning activity in learning English. This study use qualitative research. The sample of this study involved 31 students in class XI social two at SMA Cipta Mandiri in the academic year 2017/2018. In collecting the data the researchers use questionnaire of 20 (twenty) questions that relate to cooperative learning activity. The result of this study shows that most of students agreed if the teacher use cooperative learning activity in the classroom. The students though that through cooperative learning activity, the lesson more interesting and helps them acquire knowledge easily.
\end{abstract}

Keywords: Students' Perception, Cooperative Learning Actvity

\section{INTRODUCTION}

English teacher should provide a good approach in teaching their students. They need to attract the students become more interested in learning English and achieve the goals. Teaching a language not only how the students understand about the material, but also the students apply it in their daily life. Therefore, choosing a right approach is important to do. Richards and Rodgers (2014: 81) stated that there are several approaches that can be used in teaching a language, includes Communicative Language Teaching (CLT), Content-Based Instruction and Content Language Integrated Learning (CLIL), Whole language, Competency-Based Language Teaching Standards, the Common European Framework of Reference, Task-Based Language Teaching, Text-Based Instruction, The Lexical Approach, Multiple Intelligences and Cooperative Language Learning.

According to Johnson and Johnson (1999); Du (2015) in Wen (2017) "Cooperative learning is very important approach to make students engage in learning activity, they can create a small group which required individual contribution, self-learning, peer-learning, accountability and communication skills". Meanwhile, cooperative learning may be a good approach to apply in learning a language. Through cooperative learning activity, students can directly engage with the lesson, their friends and also their teacher because in cooperative learning activity students can improve their communication skill with make a lot of contact with their members of group and each students in the classroom.

Asking students' perception about how the way the teacher teaches them is important to do because it will provide a connection about what the students' need for their learning activity. It is suggested by Tudor (1996: 50 In Kourieos and Evripidou, 2013: 1) that learners' sight about effective language learning come into view to be intentionally or automatically direct their action which support their own learning and most importantly influence their positive response or opposition and dissatisfaction to teaching activities.

In the researchers' previous study, researchers try to find out the students' perception about applying cooperative learning in EFL classroom in the university level. The research is conducted to the final year students of Indonesian education study program of IKIP Siliwangi 
Bandung. The result of the research showed that the students had positive responses toward the implementation of Cooperative Learning. Furthermore, it was found that students familiar with group activities in EFL classroom. To sum up, Cooperative Learning is a good approach for the students to learn English easily. Therefore, the researchers need to know about the response of students in the senior high school level about the cooperative learning activity in English learning. This research conducted in eleventh grade students at SMA Cipta Mandiri.

\section{METHOD}

There are several types of research methods. This research used qualitative research method to find out the solution which related to the students' perception in learning English using cooperative learning and the qualitative research here is survey. The instrument in this research used questionnaire to collect the data which consists of 20 (twenty) questions that related to students' perception of the characteristics using cooperative learning in learning English. The participants of this research were held at class XI social two of SMA Cipta Mandiri. There were 31 students at class XI social two as the participants in this research. Furthermore, there were five points scale used as indicators for measuring someone perception to finding the result, namely ( $5=$ Strongly Agree, $4=$ Agree, $3=$ Undecided, $2=$ Disagree, $1=$ Strongly Disagree).

\section{RESULTS AND DISCUSSION}

\section{Result}

This study analyzed the perception of students in learning English using cooperative learning activity. In this research, there are 31 participants of SMA Cipta Mandiri who asked 20 (twenty) questions that adapted from Wichadee's study which related of cooperative learning. The study results are based on student answer from questionnaire shared to participants. The data would explain in paragraph based on the table below.

Table 1. Questionnaire number 1

\begin{tabular}{cccccc}
\hline & \multicolumn{5}{c}{ Student's Response } \\
\cline { 2 - 5 } Statement & 5 & 4 & 3 & 2 & 1 \\
& $\begin{array}{c}\text { Strongly } \\
\text { Agree }\end{array}$ & Agree & Undecided & Disagree & $\begin{array}{c}\text { Strongly } \\
\text { Disagree }\end{array}$ \\
\hline $\begin{array}{c}\text { I'm familiar with group } \\
\text { study (cooperative } \\
\text { learning) }\end{array}$ & 11 & 19 & 1 & \\
\hline
\end{tabular}

Based on the table one, eleven $(35,5 \%)$ students were strongly agreed that Cooperative Learning familiar in their classroom activity, nineteen $(61,3 \%)$ students agreed that CL familiar in their classroom activity, and one $(3,2 \%)$ students undecided that CL familiar in their classroom activity.

Table 2. Questionnaire number 2

\begin{tabular}{|c|c|c|c|c|c|}
\hline \multirow[b]{2}{*}{ Statement } & \multicolumn{5}{|c|}{ Student's Response } \\
\hline & $\begin{array}{c}5 \\
\text { Strongly } \\
\text { Agree }\end{array}$ & $\begin{array}{c}4 \\
\text { Agree }\end{array}$ & $\begin{array}{c}3 \\
\text { Undecided }\end{array}$ & $\begin{array}{c}2 \\
\text { Disagree }\end{array}$ & $\begin{array}{c}1 \\
\text { Strongly } \\
\text { Disagree }\end{array}$ \\
\hline $\begin{array}{l}\text { In English classes, teachers } \\
\text { often use group discussions } \\
\text { and activities. }\end{array}$ & 7 & 15 & 6 & 1 & 2 \\
\hline
\end{tabular}


Based on the table two, seven $(22,6 \%)$ students were strongly agreed that teachers often used group discussions and activities in EFL classroom, fifteen $(48,4 \%)$ they were agreed that teachers often used group discussions and activities in EFL classroom, six $(19,4 \%)$ students undecided that teachers often used group discussions and activities in EFL classroom, one $(3,2 \%)$ students disagreed that teachers often used group discussions and activities in EFL classroom, and two $(6,4 \%)$ strongly disagreed that teachers often used group discussions and activities in EFL classroom.

Table 3. Questionnaire number 3

\begin{tabular}{cccccc}
\hline \multirow{2}{*}{ Statement } & \multicolumn{5}{c}{ Student's Response } \\
\cline { 2 - 6 } & 5 & 4 & 3 & 2 & 1 \\
& $\begin{array}{c}\text { Strongly } \\
\text { Agree }\end{array}$ & Agree & Undecided & $\begin{array}{c}\text { Disagree } \\
\text { Strongly } \\
\text { Disagree }\end{array}$ \\
\hline $\begin{array}{c}\text { We have no much classroom } \\
\text { activities in English class. }\end{array}$ & & 2 & 5 & 18 & 6 \\
\hline
\end{tabular}

Based on the table three, two $(6,4 \%)$ students agreed that they have no much classroom activities in English classroom, five $(16,1 \%)$ undecided that they have no much classroom activities in English classroom, eighteen $(58,1 \%)$ students disagreed that they have no much classroom activities in English classroom and six $(19,4 \%)$ students were strongly disagreed that they have no much classroom activities in English class.

Table 4. Questionnaire number 4

\begin{tabular}{cccccc}
\hline \multirow{2}{*}{ Statement } & \multicolumn{5}{c}{ Student's Response } \\
\cline { 2 - 6 } & 5 & 4 & 3 & 2 & 1 \\
& $\begin{array}{c}\text { Strongly } \\
\text { Agree }\end{array}$ & Agree & Undecided & Disagree & $\begin{array}{c}\text { Strongly } \\
\text { Disagree }\end{array}$ \\
\hline I like working with groups & 5 & 21 & 2 & 3 & \\
\hline
\end{tabular}

Based on the table four, five $(16,1 \%)$ students were strongly agreed that they like worked with groups, twenty one $(67,7 \%)$ students agreed that they like worked with groups, two $(6,4 \%)$ undecided that they like worked with groups and three $(9,7 \%)$ disagreed that they like worked with groups.

Table 5. Questionnaire number 5

\begin{tabular}{cccccc}
\hline & \multicolumn{5}{c}{ Student's Response } \\
\cline { 2 - 5 } Statement & 5 & 4 & 3 & 2 & 1 \\
& $\begin{array}{c}\text { Strongly } \\
\text { Agree }\end{array}$ & Agree & Undecided & $\begin{array}{c}\text { Disagree } \\
\text { Strongly } \\
\text { Disagree }\end{array}$ \\
\hline $\begin{array}{c}\text { Group study helps me to } \\
\text { learn English easier. }\end{array}$ & 3 & 18 & 5 & 3 & 2 \\
\hline
\end{tabular}

Based on the table five, three $(9,7 \%)$ students were strongly agreed that group study helps them to learn English easier, eighteen $(58,1 \%)$ students agreed that group study helps them to learn English easier, five $(16,1 \%)$ students undecided that group study helps them to learn English easier, three $(9,7 \%)$ students disagreed that group study helps them to learn English easier, and two $(6,4 \%)$ student strongly disagreed that group study helps them to learn English easier. 
Table 6. Questionnaire number 6

\begin{tabular}{|c|c|c|c|c|c|}
\hline \multirow[b]{2}{*}{ Statement } & \multicolumn{5}{|c|}{ Student's Response } \\
\hline & $\begin{array}{c}5 \\
\text { Strongly } \\
\text { Agree }\end{array}$ & $\begin{array}{c}4 \\
\text { Agree }\end{array}$ & $\begin{array}{c}3 \\
\text { Undecided }\end{array}$ & $\begin{array}{c}2 \\
\text { Disagree }\end{array}$ & $\begin{array}{c}1 \\
\text { Strongly } \\
\text { Disagree }\end{array}$ \\
\hline $\begin{array}{l}\text { Group study helps me to } \\
\text { acquire knowledge through } \\
\text { working in a team. }\end{array}$ & 9 & 16 & 4 & 2 & 1 \\
\hline
\end{tabular}

Based on the table six, nine (29\%) students were strongly agreed that group study helps them to acquire knowledge through working in a team, sixteen $(51,6 \%)$ students agreed that group study helps them to acquire knowledge through working in a team, four $(12,9 \%)$ students undecided that group study helps them to acquire knowledge through working in a team, two $(6,4 \%)$ student disagreed that group study helps them to acquire knowledge through working in a team, and one $(3,2 \%)$ student strongly disagreed that group study helps them to acquire knowledge through working in a team.

Table 7. Questionnaire number 7

\begin{tabular}{cccccc}
\hline & \multicolumn{5}{c}{ Student's Response } \\
\cline { 2 - 5 } Statement & 5 & 4 & 3 & 2 & 1 \\
& $\begin{array}{c}\text { Strongly } \\
\text { Agree }\end{array}$ & Agree & Undecided & Disagree & $\begin{array}{c}\text { Strongly } \\
\text { Disagree }\end{array}$ \\
\hline $\begin{array}{c}\text { Group study helps me to } \\
\text { understand the working } \\
\text { process. }\end{array}$ & 7 & 20 & 2 & 1 & 1 \\
\hline
\end{tabular}

Based on the table seven, seven $(22,6 \%)$ students were strongly agreed that group study helps them to understand the working process, twenty $(64,5 \%)$ students were agreed, two $(6,4 \%)$ students undecided and one $(3,2 \%)$ student was strongly disagreed.

Table 8. Questionnaire number 8

\begin{tabular}{cccccc}
\hline & \multicolumn{5}{c}{ Student's Response } \\
\cline { 2 - 5 } Statement & 5 & 4 & 3 & 2 & 1 \\
& Strongly Agree & Agree & Undecided & Disagree & $\begin{array}{c}\text { Strongly } \\
\text { Disagree }\end{array}$ \\
\hline $\begin{array}{c}\text { This approach enables me to } \\
\text { participate in sharing } \\
\text { information, making } \\
\text { decisions, and solving } \\
\text { problems. }\end{array}$ & 5 & 24 & 2 & \\
\hline
\end{tabular}

Based on the table eight, five $(16,1 \%)$ students were strongly agreed that Cooperative Learning enables them to participate in sharing information, making decisions, and solving problems. Twenty four $(77,4 \%)$ students agreed that CL enables them to participate in sharing information, making decisions, and solving problems and two $(6,4 \%)$ undecided that CL enables them to participate in sharing information, making decisions, and solving problems. 
Table 9. Questionnaire number 9

\begin{tabular}{cccccc}
\hline \multirow{2}{*}{ Statement } & \multicolumn{5}{c}{ Student's Response } \\
\cline { 2 - 5 } & $\begin{array}{c}5 \\
\text { Strongly } \\
\text { Agree }\end{array}$ & $\begin{array}{c}4 \\
\text { Agree }\end{array}$ & $\begin{array}{c}3 \\
\text { Undecided }\end{array}$ & $\begin{array}{c}2 \\
\text { Disagree }\end{array}$ & $\begin{array}{c}\text { Strongly } \\
\text { Disagree }\end{array}$ \\
\hline $\begin{array}{c}\text { I prefer the class to have } \\
\text { more group activities rather } \\
\text { than individual study }\end{array}$ & 1 & 17 & 7 & 4 & 2 \\
\hline
\end{tabular}

Based on the table nine, one $(3,2 \%)$ students were strongly agreed that they prefer the class to have more group activities rather than individual study, seventeen $(54,8 \%)$ students agreed that they prefer the class to have more group activities rather than individual study, seven $(22,6 \%)$ students undecided that they prefer the class to have more group activities rather than individual study, four $(12,9 \%)$ students disagreed that they prefer the class to have more group activities rather than individual study and two $(6,4 \%)$ students were strongly disagreed that they prefer the class to have more group activities rather than individual study.

Table 10. Questionnaire number 10

\begin{tabular}{cccccc}
\hline & \multicolumn{5}{c}{ Student's Response } \\
\cline { 2 - 5 } Statement & 5 & 4 & 3 & 2 & 1 \\
& $\begin{array}{c}\text { Strongly } \\
\text { Agree }\end{array}$ & Agree & Undecided & $\begin{array}{c}\text { Disagree } \\
\text { Strongly } \\
\text { Disagree }\end{array}$ \\
\hline $\begin{array}{c}\text { I willingly participate in- } \\
\text { group activities. }\end{array}$ & 6 & 18 & 4 & 2 & 1 \\
\hline
\end{tabular}

Based on the table ten, six $(19,4 \%)$ students were strongly agreed that they willingly participate in-group activities, eighteen $(58,1 \%)$ agreed that they willingly participate ingroup activities, four $(12,9 \%)$ undecided that they willingly participate in-group activities, two $(6,4 \%)$ disagreed that they willingly participate in-group activities and one $(3,2 \%)$ students were strongly disagreed that they willingly participate in-group activities.

Table 11. Questionnaire number 11

\begin{tabular}{cccccc}
\hline & \multicolumn{5}{c}{ Student's Response } \\
\cline { 2 - 6 } Statement & 5 & 4 & 3 & 2 & 1 \\
& $\begin{array}{c}\text { Strongly } \\
\text { Agree }\end{array}$ & Agree & Undecided & Disagree & $\begin{array}{c}\text { Strongly } \\
\text { Disagree }\end{array}$ \\
\hline $\begin{array}{c}\text { Group study can improve my } \\
\text { attitude towards work. }\end{array}$ & 3 & 21 & 6 & 1 & \\
\hline
\end{tabular}

Based on the table eleven, three $(9,7 \%)$ students were strongly agreed that CL can improve their attitude towards work, twenty one $(67,7 \%)$ agreed that CL can improve their attitude towards work, six $(19,4 \%)$ felt undecided that CL can improve their attitude towards work and one $(3,2 \%)$ students disagreed that CL can improve their attitude towards work.

Table 12. Questionnaire number 12

Statement Student's Response

$4 \quad 3 \quad 2 \quad 1$
$\begin{array}{lllll}5 & 4 & 3 & 2 & 1\end{array}$ Strongly Agree Undecided Disagree Strongly Agree Disagree 


\begin{tabular}{cccccc}
$\begin{array}{c}\text { I don't like teachers' } \\
\text { intervention when we do } \\
\text { group work }\end{array}$ & 1 & 12 & 7 & 9 & 2 \\
\hline
\end{tabular}

Based on the table twelve about the statements that students don't like when the their teacher intervention when they do group work, there was one $(3,2 \%)$ student strongly agreed about that statement and twelve $(38,7 \%)$ students agreed. Then, seven $(22,6 \%)$ undecided that they do not like teachers' intervention when they do group work, nine (29\%) disagreed that they do not like teachers' intervention when they do group work, and two $(6,4 \%)$ strongly disagreed that they do not like teachers' intervention when they do group work.

Table 13. Questionnaire number 13

\begin{tabular}{cccccc}
\hline \multirow{2}{*}{ Statement } & \multicolumn{5}{c}{ Student's Response } \\
\cline { 2 - 5 } & $\begin{array}{c}5 \\
\text { Strongly } \\
\text { Agree }\end{array}$ & $\begin{array}{c}4 \\
\text { Agree }\end{array}$ & $\begin{array}{c}3 \\
\text { Undecided }\end{array}$ & $\begin{array}{c}2 \\
\text { Disagree }\end{array}$ & $\begin{array}{c}\text { Strongly } \\
\text { Disagree }\end{array}$ \\
\hline $\begin{array}{c}\text { I think interaction can } \\
\text { improve English more than } \\
\text { just learning from teachers }\end{array}$ & 9 & 18 & 3 & 1 & \\
\hline
\end{tabular}

Based on the table thirteen, nine (29\%) students were strongly agreed that interaction can improve English more than just learning from teachers, eighteen $(58,1 \%)$ students were agreed, three $(9,7 \%)$ undecided and one $(3,2 \%)$ about that statement.

Table 14. Questionnaire number 14

\begin{tabular}{cccccc}
\hline & \multicolumn{5}{c}{ Student's Response } \\
\cline { 2 - 6 } Statement & 5 & 4 & 3 & 2 & 1 \\
& $\begin{array}{c}\text { Strongly } \\
\text { Agree }\end{array}$ & Agree & Undecided & Disagree & $\begin{array}{c}\text { Strongly } \\
\text { Disagree }\end{array}$ \\
\hline $\begin{array}{c}\text { This approach helps } \\
\text { everyone reach the goal } \\
\text { equally }\end{array}$ & 1 & 15 & 5 & 6 & 4 \\
\hline
\end{tabular}

Based on the table fourteen, one $(3,2 \%)$ students was strongly agreed, fifteen $(48,4 \%)$ students were agreed, five $(16,1 \%)$ students were undecided, six $(19,4 \%)$ students were disagreed and four $(12,9 \%)$ students were strongly disagreed that cooperative learning approach helps everyone reach the goal equally.

Table 15. Questionnaire number 15

\begin{tabular}{cccccc}
\hline & \multicolumn{5}{c}{ Student's Response } \\
\cline { 2 - 5 } Statement & 5 & 4 & 3 & 2 & 1 \\
& $\begin{array}{c}\text { Strongly } \\
\text { Agree }\end{array}$ & Agree & Undecided & $\begin{array}{c}\text { Disagree } \\
\text { Strongly } \\
\text { Disagree }\end{array}$ \\
\hline $\begin{array}{c}\text { This approach trains me how } \\
\text { to be a good leader and a } \\
\text { good follower }\end{array}$ & 4 & 18 & 6 & 1 & 2 \\
\hline
\end{tabular}

Based on the table fifteen, four $(12,9 \%)$ students were strongly agreed that cooperative learning approach trains them how to be a good leader and a good follower, eighteen $(58,1 \%)$ 
were agreed that cooperative learning approach trains them how to be a good leader and a good follower, six $(19,4 \%)$ were undecided that cooperative learning approach trains them how to be a good leader and a good follower, one $(3,2 \%)$ students were disagreed that cooperative learning approach trains them how to be a good leader and a good follower and two $(6,4 \%)$ students were strongly disagreed that cooperative learning approach trains them how to be a good leader and a good follower.

Table 16. Questionnaire number 16

\begin{tabular}{cccccc}
\hline & \multicolumn{5}{c}{ Student's Response } \\
\cline { 2 - 5 } Statement & 5 & 4 & 3 & 2 & 1 \\
& $\begin{array}{c}\text { Strongly } \\
\text { Agree }\end{array}$ & Agree & Undecided & Disagree & $\begin{array}{c}\text { Strongly } \\
\text { Disagree }\end{array}$ \\
\hline $\begin{array}{c}\text { This approach creates a good } \\
\text { relation- ship among group } \\
\text { members }\end{array}$ & 6 & 17 & 5 & 3 & \\
\hline
\end{tabular}

Based on the table sixteen, six $(19,4 \%)$ students were strongly agreed that cooperative learning approach creates a good relation- ship among group members, seventeen $(54,8 \%)$ were agreed that cooperative learning approach creates a good relation- ship among group members, five $(16,1 \%)$ were undecided that cooperative learning approach creates a good relation- ship among group members and three $(9,7 \%)$ were disagreed that cooperative learning approach creates a good relation- ship among group members.

Table 17. Questionnaire number 17

\begin{tabular}{|c|c|c|c|c|c|}
\hline \multirow[b]{2}{*}{ Statement } & \multicolumn{5}{|c|}{ Student's Response } \\
\hline & $\begin{array}{c}5 \\
\text { Strongly } \\
\text { Agree }\end{array}$ & $\begin{array}{c}4 \\
\text { Agree }\end{array}$ & $\begin{array}{c}3 \\
\text { Undecided }\end{array}$ & $\begin{array}{c}2 \\
\text { Disagree }\end{array}$ & $\begin{array}{c}1 \\
\text { Strongly } \\
\text { Disagree }\end{array}$ \\
\hline $\begin{array}{l}\text { The lessons become more } \\
\text { interesting with this } \\
\text { approach. }\end{array}$ & 9 & 20 & & 2 & \\
\hline
\end{tabular}

Based on the table seventeen, nine (29\%) students were strongly agreed that the lesson become more interesting with cooperative learning approach, twenty $(64,5 \%)$ were agreed that the lesson become more interesting with cooperative learning approach and two $(6,4 \%)$ students were disagreed that the lesson become more interesting with cooperative learning approach.

Table 18. Questionnaire number 18

\begin{tabular}{llllll}
\hline \multirow{2}{*}{ Statement } & \multicolumn{4}{l}{ Student's Response } & \\
\cline { 2 - 6 } & 5 & 4 & 3 & 2 & 1 \\
& $\begin{array}{l}\text { Strongly } \\
\text { Agree }\end{array}$ & Agree & Undecided & $\begin{array}{l}\text { Disagree } \\
\text { Strongly } \\
\text { Disagree }\end{array}$ \\
\hline $\begin{array}{l}\text { I feel actively involved in all } \\
\text { activities through this } \\
\text { approach. }\end{array}$ & & 19 & 3 & 1 & \\
\hline
\end{tabular}

Based on the table eighteen the statement was the students feel actively involved in all activities through cooperative learning approach. There are eight $(25,8 \%)$ students were 
strongly agreed about that statement, nineteen $(61,3 \%)$ students agreed, three $(9,7 \%)$ students undecided and one $(3,2 \%)$ student was disagreed.

Table 19. Questionnaire number 19

\begin{tabular}{cccccc}
\hline \multirow{2}{*}{ Statement } & \multicolumn{5}{c}{ Student's Response } \\
\cline { 2 - 5 } & $\begin{array}{c}5 \\
\text { Strongly } \\
\text { Agree }\end{array}$ & $\begin{array}{c}4 \\
\text { Agree }\end{array}$ & $\begin{array}{c}\text { Undecided } \\
\text { Undery }\end{array}$ & $\begin{array}{c}2 \\
\text { Disagree }\end{array}$ & $\begin{array}{c}\text { Strongly } \\
\text { Disagree }\end{array}$ \\
\hline $\begin{array}{c}\text { I feel intellectually } \\
\text { challenged through this } \\
\text { approach }\end{array}$ & 3 & 18 & 4 & 4 & 2 \\
\hline
\end{tabular}

Based on the table nineteen, three $(9,7 \%)$ students were strongly agreed feel intellectually challenged through cooperative learning approach, eighteen $(58,1 \%)$ students were agreed. Then, four $(12,9 \%)$ students were undecided feel intellectually challenged through cooperative learning approach, four $(12,9 \%)$ students were disagreed feel intellectually challenged through cooperative learning approach and two $(6,4 \%)$ students strongly disagreed feel intellectually challenged through cooperative learning approach.

Table 20. Questionnaire number 20

\begin{tabular}{cccccc}
\hline \multirow{2}{*}{ Statement } & 5 & 4 & 3 & 2 & 1 \\
\cline { 2 - 6 } & $\begin{array}{c}\text { Strongly } \\
\text { Agree }\end{array}$ & Agree & Undecided & $\begin{array}{c}\text { Sisagree } \\
\text { Strongly } \\
\text { Disagree }\end{array}$ \\
\hline $\begin{array}{c}\text { I cooperate much in the } \\
\text { group. I wish teacher could } \\
\text { use more group study and } \\
\text { activities in the class. }\end{array}$ & 8 & 17 & 3 & 3 & \\
\hline
\end{tabular}

Based on the table twenty, eight $(2,85 \%)$ students were strongly agreed that they cooperate much in the group and wish teacher could use more group study and activities in the class, seventeen $(54,8 \%)$ agreed that they cooperate much in the group and wish teacher could use more group study and activities in the class, three $(9,7 \%)$ undecided that they cooperate much in the group and wish teacher could use more group study and activities in the class, and three $(9,7 \%)$ students were disagreed that they cooperate much in the group and wish teacher could use more group study and activities in the class.

\section{Discussion}

Based on the data result, show that most students at least $(60 \%)$ were familiar with group study and they like when their teacher apply the cooperative learning in the classroom. The students feel more engage with their friend and easier to learn English, acquire knowledge and achieve the goal of learning. Moreover, there are more than $(50 \%)$ students also think that group work activity can improve their attitude and their interaction in the classroom. Therefore, the use of cooperative learning activity in learning English in senior highschool level, especially in SMA Cipta Mandiri was effective to apply because the survey shows that students give positive responses. It means, cooperative learning may be good approach to apply in learning activity because all of elements can engage and have a good interaction and enrich the knowledge. 


\section{CONCLUSION}

The result of this study indicates that perception of using group work or cooperative learning in learning English gives good effect for students. Based on the result, the data show that using group activity helps students in learning English and most of the students agreed that this approach helps them to get the knowledge through working in a team easily and make the learning process more interesting. Moreover, students believe that through cooperative learning can enables to participate in sharing information, making decisions, intellectually challenge and solving problems. Based on the students' perception, cooperative learning make good impact for the students to reach the goals of the learning language; it means that cooperative learning is one of the effective approaches to apply especially in learning English. The researcher suggest that the teacher should be developing perception to students about the good English through cooperative learning and make students feel enjoy in learning English with more activity group.

\section{ACKNOWLEDGMENTS}

Alhamdulilahirobbil 'alamin, praise for Allah SWT for all the blessing and grace to enable us to complete this journal entitled Students' perception in learning English using cooperative learning. This journal is a requirement for accomplishing S-1 degree in English Education department, IKIP Siliwangi, Cimahi.

The researchers greatest appreciation also goes to Dr. Irma Savitri Sadikin M. Pd as The Head of English Education Study Program. We also want to deliver our sincere thank to IntanSatriani, M.pd as our advisor. Thank you for all your suggestions and guidance which are useful to finish our journal. We also thank to all lecturers in English Education Program for all your time to share your knowledge.

Nobody has been more important to us in the pursuit of this project than the members of our family. We would like to thank our parents, whose love and guidance are with us in whatever we are pursue. 
216 Kharisma, Hidayati, Students' Perception in Learning ...

\section{REFERENCES}

Kourieos, S., \& Evripidou, D. (2013). Students' Perceptions of Effective EFL Teachers in University Settings in Cyprus. English Language Teaching: Vol. 6, Number 11: 2013. Canadian Center od Science and Education

Richards, J.C., \& Rodgers, T.S. (2014). Approaches and Methods in Language Teaching. February 01, 2018. Cambridge University Press. Retrived from https://books.google.co.id/books?id=HrhkAwAAQBAJ\&dq=kinds+of+approach+and+t echniques+in+teaching+english\&lr $=\& h l=i d \&$ source $=$ gbs_navlinks_s

Wen, L. (2017). The Perceptions of Students on Cooperative Learning at Intermediate Accounting II Course. Bussiness Education Innovation Journal. Vol. 9. No. 2. Emporia State University, USA. 